\title{
Integrated Anaerobic-Aerobic Sequencing Batch Reactors for Unrestricted Reuse Using Greywater Treatment
}

\author{
Sarath Chandra Pragada and Arun Kumar Thalla
}

\begin{abstract}
This work is carried out to evaluate the efficiency of the pilot scale integrated scheme which comprises of an Anaerobic Sequence Batch Reactor (AnSBR) reactor, Aerobic Sequence Batch Reactor (ASBR), and sand filter for the elimination of organic matter and nutrient in synthetic greywater. The treatment effectiveness of the pilot plant was identified based on its pollutant removal efficiency for 12 months. The AnSBR removes 49.64, 64.24, 55.35, 87.82, 54.36, 32.73, 72.61, 34.88, and 72.11\% of Chemical Oxygen Demand (COD), Biochemical Oxygen Demand (BOD), Total Nitrogen (TN), anionic surfactant, Total Phosphorous (TP), Ammonium Nitrogen $\left(\mathrm{NH}_{4}{ }^{+}-\mathrm{N}\right)$, Total Suspended Solids (TSS), Nitrate Nitrogen $\left(\mathrm{NO}_{3}{ }^{-}-\mathrm{N}\right)$ and sulphates, respectively. Moreover, the removal efficiencies are improved to $84.27,86.04,80.8,95.13$, 80.55, 90.23, 72.98, and $75.45 \%$, respectively, in the ASBR with an additional aeration period. The removal efficiencies of $C O D$, BOD, TN, anionic surfactant, TP, TSS, $\mathrm{NH}_{4}{ }^{+}-\mathrm{N}, \mathrm{NO}_{3}{ }^{-}-\mathrm{N}$, and sulphates have been improved progressively to $89.12,94.9,85.15$ $99,86.98,88.54,93.52,94.89$, and $80.49 \%$, respectively in the sand filter. In tracer studies, that a total of $29.3 \%$ of the salt has been remained in the reactor which suggests a good deal of salt of the integrated system. Furthermore, this hydrodynamic study discloses a moderately low volume $(30.3 \%)$ for the integrated system with the mean residence time is lesser than theoretical hydraulic residential time. Based on these findings, it is evident that the integrated anaerobic-aerobic system bounded with the sand filter process accomplishes the achievement of efficiency.
\end{abstract}

Index Terms-Aerobic reactor, anaerobic reactor, greywater, hydrodynamic studies, $\mathrm{NaCl}$ purge, sand filter.

\section{INTRODUCTION}

Global water shortage has been a principal issue over the years because of the population growth combination, increasing lifestyle standard, increased urbanization, nutritional changes, water resources mismanagement, and climate variations [1]. Water management is required to maintain as well as improve water distribution and sanitation. Management of wastewater is important to eliminate water scarcity and to protect all types of ecosystems. The increasing demand for finite and irreplaceable water resources has stimulated innovative plan of action for freshwater governance, including technology innovation for recycling of wastewater. Source separation of wastewater can resolve the

Manuscript received May 31, 2021; revised June 22, 2021. This work was supported by a research project titled "Small scale and sustainable household greywater recycling (S3HWR)"; under Grant No. IMPRINT 5670 is funded by the Government of India MHRD \& MOUD.

The authors are with the Department of Civil Engineering, National Institute of Technology, Mangalore, Karnataka, 575025, India (corresponding author: Sarath Chandra Pragada; e-mail: sarathpragada@gmail.com, arunkumar@ nitk.edu.in). problem of conventional water treatment which requires complex methods for treatment since the several types of wastewater flow from the residential area mixes with clean water and have limited options regarding the recycling of wastewater components. In the source separation process, greywater (bathroom, kitchen, and laundry water), blackwater (urine, faces, and flush water), and yellow water (only urine) are separated from wastewater [2], [3]. Water treatment plants should be able to handle with the changes in the composition of wastewater and the daily variability in flow.

Greywater reuse and recycling can be the essential practice to decrease the demand for drinking water. Reuse of treated greywater can save approximately $50 \mathrm{~L}$ of potable water in a common household every single day [4], [5]. Greywater is the discharge that is created by the kitchen sinks, showers, baths, bathroom sinks, and laundry. Characteristics of greywater fluctuate according to the consumer's lifestyle, cultural and social behavior. It has the lowest micro and macro contaminants compared to other wastewaters (e.g., black water). Hence, the source of separation of municipal sewers into grey and black streams has been promoted to maximize the recycling possibility and minimize the required energy for the treatment [6]-[8].

The unconcentrated domestic wastewater streams are produced from laundry facilities, shower, and washbasins constitute the greywater, and greywater involves the kitchen wastewater too [9], [10]. The greywater gives a contribution of $60-75 \%$ to domestic wastewater of the total water volume including a release of $\mathrm{N}, \mathrm{P}, \mathrm{K}$, and organic matter in the rate of $9-14 \%, 20-32 \%, 18-22 \%$, and $29-62 \%$ respectively [11]. Greywater normally contains a low level of contaminating pathogens. Urine is not included in greywater as it has a negligible quantity of nitrogen, in particulate form derived from organic nitrogen [12]. There are a lot of methods that have been used to remove organic contaminants in greywater including physical, chemical, and biological methods, as shown in Fig. 1.

Physical and substance cycles can crash suspended solids, natural matter, and microbes, however, are generally less equipped for eliminating supplements [13], [14]. Organic cycles can frequently fill in as a superior decision, permitting the expulsion of supplements, keeping away from the utilization of synthetics, lessening the expenses and effects on the climate. Treatments are employed for diminishing the contaminants level in the gravel previously reprocess or the final disposal. They are impurity explicit that is applied to the ordinary process of wastewater treatment grouping including pre-treatment, essential, tertiary and optional treatment. Thus, every system in this process involves the biological or the physio chemical treatment.

Several biological techniques have been applied for 
greywater treatment, including; membrane bioreactor, constructed wetlands, AnSBR, rotating biological contactors (RBC), and ASBR [15]. Among these, the sequential batch reactors (SBR) systems are advantageous due to the possibility to carry out the removal of substrates in a single unit, with a small footprint due to the absence of secondary clarifiers. The effluents produced from SBR treatment of greywater satisfied most of the conventional pollutant standards of wastewater reuse. The SBR scheme is attributed to a high tractability for the operation as well as the time-controlled sequence, which are considered as the necessary pollutant reducing method [16], [17]. The AnSBR process is best fit for performing the greywater anaerobic treatment. Additionally, the AnSBR process can enables the expulsion in an effective manner based on organic loads like $\mathrm{BOD}_{5}$, oil, COD, and grease. This process is utilized for removing the phosphate and nitrogen compound concentrations. In addition, the biological degeneration of the sludge can be accomplished by the AnSBR, with the production of biogas as a source of green energy [18].

Meanwhile, the aeration method has demonstrated the effectual approach for diminishing the various pollutants in the wastewater. Moreover, the existing developed aeration processes are depending on the air supply for the effective treatment scheme. Abdel-Shafy et al. [19], Albalawneh and Chang [20] studied the anaerobic biodegradability of greywater and found $70 \%$ biodegradability and removal of nitrogen as $22-30 \%$ and phosphorous as $15-21 \%$ in the greywater. Moreover, the anaerobic reduction needs further improvement and can be followed by an aerobic system [21]. Abu Ghunmi et al. [22] carried out the process of greywater treatment based on the anaerobic-aerobic schemes for the irrigation. The anaerobic and aerobic units achieved $45 \%, 39 \%$ COD removal in summer, and 53\%, 64\% COD removal in winter respectively. Except for pathogens, aerobic effluent quality agreed using the proposed irrigation guidelines of water quality for water recovered in Jordan.

Gašpariková et al. [23] evaluated anaerobic-aerobic wastewater treatment plant operations to have many benefits and it is performed to overcome the limitations of the methods like aerobic and anaerobic. By combining these methods into a single integrated scheme through the anaerobic pre-treatment process as well as aerobic post-treatment process it obtained high efficiency for removing the organic matter, low specific energy needs, biogas development, relatively short confinement period, and low specific development of excess sludge [24]. However, SBR systems are less efficient in eliminating total suspended solids (TSS) despite the high reduction in most of the other organic contaminants in greywater treatment [25]. So, filtration is one of the low-cost techniques used as a post-treatment unit to remove turbidity, colloids, and suspended solids.

The main reason for treating the greywater in low or middle-income countries is because of public health issues concern. If the greywater is not treated then the people in those countries would suffer a lot from the dangerous diseases. Also, the medical facilities are also not as much upgraded in those low. So, to protect people life from diseases, the greywater must be treated. In addition, people in these countries often use greywater because of inadequate water facilities. Hence, reusing the greywater is a good idea to compensate for the inadequate water facilities, but that greywater should be treated before reuse.

The objective of the present research work is summarized as follows,

- To treat the greywater for reuse, a novel frame work has been proposed.

- To examine the purity of the greywater after the process of treatment.

- To evaluate long-term performance while removing the organic matter, suspended solids, and nutrients.

- To estimate hydrodynamic characteristics of the greywater treatment in the integrated system.

- To compare the proposed greywater treatment design with existing models.

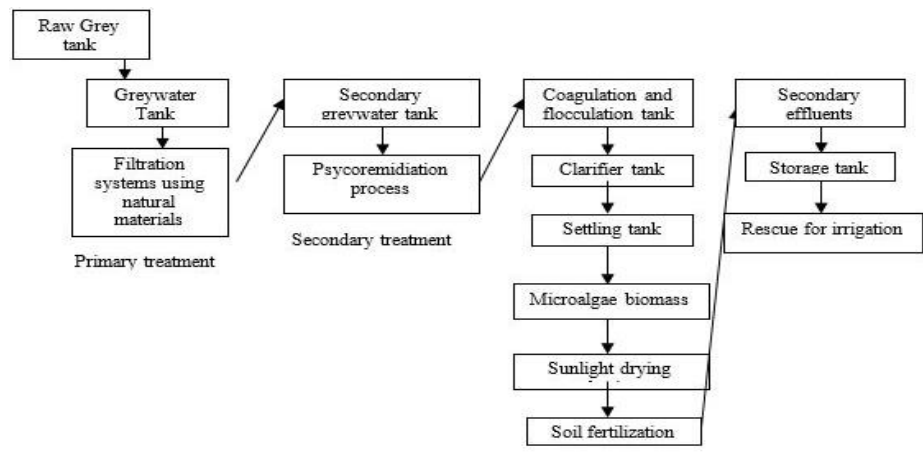

Fig. 1. Hybrid system for treatment of household greywater [26].

\section{MAterials AND METHODS}

All the experimental investigations were carried out using synthetic greywater in a pilot plant fabricated in the environmental engineering lab, National Institute Technology Karnataka (NITK), Surathkal, India.

\section{A. Integrated Greywater Treatment Plant Design and Operation}

TABLE I: DESIGN OF HOLDING TANK, ANSBR REACTOR, ASBR, AND SAND

\begin{tabular}{lccc}
\hline \multicolumn{3}{c}{ FILTER } \\
Operational parameters & $\begin{array}{c}\text { Diameter } \\
(\mathrm{m})\end{array}$ & $\begin{array}{c}\text { Height } \\
(\mathrm{m})\end{array}$ & $\begin{array}{c}\text { Total volume } \\
\left(\mathrm{m}^{3}\right)\end{array}$ \\
\hline Holding tank & 0.4 & 0.77 & 0.2 \\
AnSBR & 0.55 & 0.87 & 0.2 \\
ASBR & 0.55 & 0.87 & 0.2 \\
Sand Filter & 0.30 & 0.53 & 0.04 \\
\hline \hline
\end{tabular}

The integrated greywater treatment plant consists of two same size greywater influent holding tanks, namely, the AnSBR, and the ASBR followed by a sand filter, to exterminate suspended solids and coarse organic matter from the water that is treated by anaerobic reactor, which is given in Fig. 2. The design detail of the whole integrated greywater treatment is shown in Table I. The entire setup was made of non-transparent PVC tanks. The treatment unit has been operated with an automated configuration of 6 cycles. The typical duration of each cycle is four hours, with 24-hour Hydraulic Retention Time (HRT). This process has been subsequently channeled using ASBR fitted through the aeration pump that is diversified for $12 \mathrm{~h}$ to achieve the desired final effluent quality with the loading rate of 2.6 
$\mathrm{kgBOD}_{5} / \mathrm{m}^{3} /$ day. In ASBR, air flowrate is provided using air pump with maximum of $660 \mathrm{~L} / \mathrm{h}$ and dissolved oxygen concentration is maintained at $1-3 \mathrm{mg} / \mathrm{L}$.

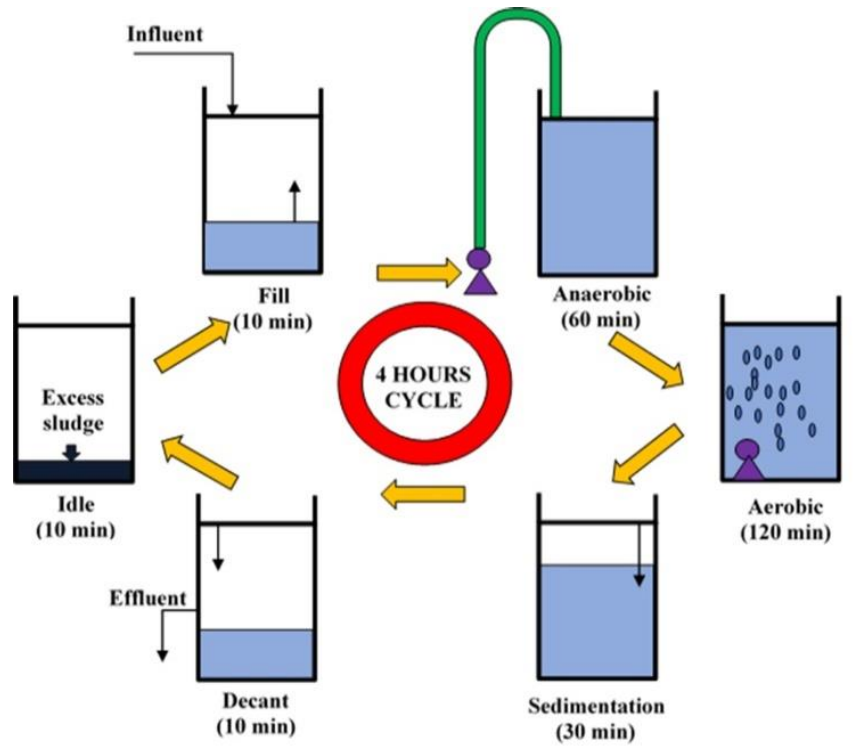

Fig. 2. Typical layout and operating procedure for greywater treatment using a combined anaerobic-aerobic-sand filter system.

\section{B. Feed and Sludge Preparation}

Synthetic greywater is prepared by mixing arrowroot powder (starch), detergent, Urea (laboratory/analytical grade), Potassium dihydrogen phosphate, liquid handwash and milk powder to feed the pilot-scale plant. The quantity of feed sample is around $100 \mathrm{~L} /$ day which inflows into the integrated system. In this Sequencing Batch Reactor (SBR) the feed has been provided in a multi-stage. So, the flow rate is maintained at around $0.85 \mathrm{~L} / \mathrm{min}$ in each cycle.

On the other hand, the inoculum was supplemented with macronutrients, micronutrients, and $\mathrm{pH}$ was adjusted to 7.5-8 before filling the reactor. Subsequently, the anaerobic reactor was filled with $100 \mathrm{~L}$ of anaerobic sludge at mixed liquor volatile suspended solids (MLVSS) concentration of 1000-1500 mg/L. Meanwhile, the aerobic reactor was filled with $100 \mathrm{~L}$ of aerobic sludge at MLVSS concentration of $1500-2000 \mathrm{mg} / \mathrm{L}$ on day one of operation.

\section{Sand Filter Media}

The gravel and sand provided in sacks were washed in tap water thoroughly before filling in the plastic drum. The empty Volume (up to the outlet) of the tank is $70 \mathrm{~L}$. There were two grades of gravel and one grade of sand provided. Take $20 \mathrm{~L}$ of the biggest gravel and spread it evenly in the tank. On top of it, the smaller gravel was spread $(20 \mathrm{~L})$. Finally, on top of it, for the volume of $10 \mathrm{~L}$, the sand particles of 1-2 mm were spread. The sand provided in sacks was sieved in standard sieve sizes $(1-2 \mathrm{~mm})$, followed by thorough washing in tap water to remove dirt. The filling of gravel and sand was carried out with constant tapping and spread evenly. The media selection and design parameters of the sand filter have been represented in Table II.

The relationship among dry density, specific gravity and void ratio is shown in (1):

$$
\rho_{d}=\frac{G \rho_{w}}{(1+e)}
$$

where $G$ is specific gravity, e is void ratio, $\rho_{\mathrm{d}}$ is dry density $\left(\mathrm{kg} / \mathrm{m}^{3}\right)$ and $\rho_{\mathrm{w}}$ is density of water $\left(\mathrm{kg} / \mathrm{m}^{3}\right)$

The porosity of the filter media was then determined based on void ratio is given as follows (2):

$$
n=\frac{\mathrm{e}}{1+e}
$$

where $n=$ porosity $(\%)$.

The calculations of each layer as well as overall void ratio and porosity of the entire sand filter are described as follows.

- Bottom layer (20 mm size crushed stone)

Specific gravity $(\mathrm{G})=2.884$

Water density $\left(\rho_{w}\right)=1000 \mathrm{~kg} / \mathrm{m}^{3}$

Dry density $\left(\rho_{d}\right)=\frac{\text { Weight of } 20 \mathrm{~mm} \text { size crushed stone }}{\text { Unit Volume }}=\frac{1.55 \mathrm{~kg}}{1 \mathrm{~L}}$

$=1550 \mathrm{~kg} / \mathrm{m}^{3}$

From (1), $1550=\frac{2.884 \times 1000}{(1+e)}$

Void ratio $(\mathrm{e})=0.86$

From (2), Porosity $(\mathrm{n})=\frac{\mathrm{e}}{1+e}=\frac{0.86}{1.86}=0.4623$ (or $46.23 \%$ )

\begin{tabular}{|c|c|c|c|}
\hline Layer & $\begin{array}{l}\text { Depth } \\
\text { (m) }\end{array}$ & Filter medium & $\begin{array}{l}\text { Grain size curve } \\
\text { analysis }\end{array}$ \\
\hline Bottom layer & 0.21 & $\begin{array}{l}\text { Crushed stone } \\
\text { (20 mm size) }\end{array}$ & $\begin{array}{l}D_{10}=13.68 \mathrm{~mm} \\
D_{30}=17.66 \mathrm{~mm} \\
D_{60}=26.46 \mathrm{~mm} \\
C_{U}=1.93 \\
C_{C}=0.86 \\
e=0.86 \\
n=46.23 \%\end{array}$ \\
\hline $\begin{array}{l}\text { Transition } \\
\text { layer }\end{array}$ & 0.14 & $\begin{array}{l}\text { Crushed stone } \\
\text { (12 mm size) }\end{array}$ & $\begin{array}{l}\mathrm{D}_{10}=6.98 \mathrm{~mm} \\
\mathrm{D}_{30}=10.3 \mathrm{~mm} \\
\mathrm{D}_{60}=11.48 \mathrm{~mm} \\
\mathrm{C}_{\mathrm{U}}=1.65 \\
\mathrm{C}_{\mathrm{C}}=1.32 \\
\mathrm{e}=0.713 \\
\mathrm{n}=41.6 \%\end{array}$ \\
\hline Top layer & 0.1 & $\begin{array}{l}\text { Coarse sand } \\
(1-2 \mathrm{~mm} \text { size })\end{array}$ & $\begin{array}{l}\mathrm{D}_{10}=1.0 \mathrm{~mm} \\
\mathrm{D}_{30}=1.4 \mathrm{~mm} \\
\mathrm{D}_{60}=1.83 \mathrm{~mm} \\
\mathrm{C}_{U}=1.85 \\
\mathrm{C}_{C}=3.69 \\
\mathrm{e}=0.476 \\
\mathrm{n}=32.25 \%\end{array}$ \\
\hline
\end{tabular}

TABLE II: CHARACTERISTICS OF THE FILTER MEDIA

- Transition layer (12 mm size crushed stone)

Specific gravity $(\mathrm{G})=2.878$

Water density $\left(\rho_{w}\right)=1000 \mathrm{~kg} / \mathrm{m}^{3}$

Dry density $\left(\rho_{d}\right)=\frac{\text { Weight of } 12 \mathrm{~mm} \text { size crushed stone }}{\text { Unit Volume }}=\frac{1.68 \mathrm{~kg}}{1 \mathrm{~L}}$

$=1680 \mathrm{~kg} / \mathrm{m}^{3}$

From $(1), 1680=\frac{2.878 \times 1000}{(1+e)}$

Void ratio $(\mathrm{e})=0.713$

From (2), Porosity (n) $=\frac{\mathrm{e}}{1+e}=\frac{0.713}{1.713}=0.416$ (or 41.6\%)

- Top layer (1-2 mm size coarse sand)

Specific gravity $(\mathrm{G})=2.605$

Water density $\left(\rho_{w}\right)=1000 \mathrm{~kg} / \mathrm{m}^{3}$

Dry density $\left(\rho_{d}\right)=\frac{\text { Weight of } 1-2 \mathrm{~mm} \text { size coarse sand }}{\text { Unit Volume }}=$ $\frac{1.765 \mathrm{~kg}}{1 \mathrm{~L}}=1765 \mathrm{~kg} / \mathrm{m}^{3}$ 
From $(1), 1765=\frac{2.605 \times 1000}{(1+e)}$
Void ratio $(e)=0.476$

From (2), Porosity $(\mathrm{n})=\frac{\mathrm{e}}{1+e}=\frac{0.476}{1.476}=0.3225$ (or $32.25 \%$ )

- Overall sand filter (3 layers combined)

Specific gravity $(\mathrm{G})=2.7$

Water density $\left(\rho_{w}\right)=1000 \mathrm{~kg} / \mathrm{m}^{3}$

Dry density $\left(\rho_{d}\right)$

$=$

Weight of (20 mm crushed stone $+12 \mathrm{~mm}$ crushed stone $+1-2 \mathrm{~mm}$ coarse sand) $=\frac{1.55 \mathrm{~kg}}{1 \mathrm{~L}}+\frac{1.68 \mathrm{~kg}}{1 \mathrm{~L}}+\frac{1.765 \mathrm{~kg}}{1 \mathrm{~L}}=1665 \mathrm{~kg} / \mathrm{m}^{3}$

From $(1), 1665=\frac{2.7 \times 1000}{(1+e)}$

Void ratio $(\mathrm{e})=0.622$

From (2), Porosity $(\mathrm{n})=\frac{\mathrm{e}}{1+e}=\frac{0.622}{1.622}=0.3835($ or $38.35 \%)$

\section{Sampling and Analysis}

Here, four numbers of sampling points are used for collecting samples of greywater on two times in a week. The sampling locations were preparation tanks, AnSBR effluent, ASBR effluent and effluent of the sand filter and for gathering the samples of wastewater for performing the physicochemical analysis.

Moreover, the collected samples have to label as well as subject for the quality analysis, and usually stored in the deep freeze. Additionally, the parameters like total dissolved solids (TDS), pH, Temperature, and electrical conductivity (EC) are calculated with the use of HANNA digital instruments. Moreover, BOD, Turbidity, ammonium nitrogen $\mathrm{NH}_{4}^{+}-\mathrm{N}$ (Nessler method), TSS, anionic surfactants, sulphates, total phosphorous (TP), and nitrate nitrogen $\left(\mathrm{NO}_{3}^{-}-\mathrm{N}\right)$ (Brucine method), chemical oxygen demand (COD) (potassium dichromate reactor digestion), are performed under the important methods based on the investigation of water as well as wastewater procedures. Furthermore, Persulfate method (4500-N C) has been used to analyze the total nitrogen (TN) concentration in the influent and effluent samples [27].

\section{E. Tracer Studies}

The tracer experiment is defined as an indirect process for calculating the flow, characterizing sludge, and the properties of filter media. The feed water has supplied to the tap water furnace at a constant flow rate that maintains a 24-hour HRT while performing the tracer inspection. Additionally, this experimentation is processed after 12 months of the system operation. Moreover, for testing, the samples are obtained continuously using the outlet chamber until the pulse tracer was added to the influx stream and at least twice the HRD or tracer's concentration was reached [28]. Also, this experimentation in the integrated mechanism was analyzed by influencing with sodium chloride $(\mathrm{NaCl})$ that is combined using the influential (electrical conductivity (EC) initial pulse of $733 \mathrm{~S}$ ), the EC was monitored as the pilot plant exited each cycle, i.e. using the EC return to create the turning curve 4 hours [29]. Subsequently, the $\mathrm{NaCl}$ concentration has been computed based on the $\mathrm{NaCl}$ balance in the reactor.

The exit tracer sample time (D) and concentrations (C) are normalized through theoretical hydraulic retention time (D), and input tracer concentration $(\mathrm{C} 0)$ respectively. Also, the
Mean retention time $(\overline{\mathrm{t}})$, variance $\left(\sigma^{2}\right)$, dimensionless time $(\theta)$, $\mathrm{F}(\mathrm{t})$, and dispersion number (D/UL) are determined by (3), (4), (5), (6), (7) and (8).

$$
\begin{gathered}
\text { Mean retention time, } \bar{t}, \min =\frac{\int_{0}^{\infty} t C(t) d t}{\int_{0}^{\infty} C(t) d t} \\
\text { Variance, } \sigma^{2}=\frac{\int_{0}^{\infty}(t-\bar{t})^{2} \times C(t) d t}{\int_{0}^{\infty} C(t) d t} \\
\sigma_{\theta}^{2}=\frac{\sigma^{2}}{\bar{t}^{2}}
\end{gathered}
$$

Dispersion number, $\mathrm{D} / \mathrm{UL}=\sigma_{\Theta}{ }^{2} / 2$

$$
F(t)=\frac{\text { Tracer }_{\text {before }}-\text { Tracer }_{t}}{\text { Tracer }_{\text {before }}-\text { Tracer }_{\text {after }}}
$$

Dimensionless time, $\theta=T / \bar{t}$

An amount of dead spots in the integrated system is estimated based on the mean and theoretical HRT ratio that is given in (9).

$$
V_{d}=\left(1-\frac{\bar{t}}{t}\right) \times 100
$$

\section{RESULTS AND DISCUSSION}

\section{A. Performance Evaluation of Integrated Greywater Treatment}

The daily sampling program was developed for collecting the synthetic greywater for identifying the features like physical and chemical. Subsequently, the values of $\mathrm{pH}, \mathrm{EC}$, $\mathrm{COD}, \mathrm{BOD}_{5}, \mathrm{NH}_{4}^{+}-\mathrm{N}$, anionic surfactants, and TP for synthetic greywater were 7.1, 262.35, 347.87, 262.35, 24.26, 46.44, and $6.53 \mathrm{mg} / \mathrm{L}$, separately. The nitrate-nitrogen $\left(\mathrm{NO}_{3}^{-}-\mathrm{N}\right)$ and the TN were 8.8 and $40.73 \mathrm{mg} / \mathrm{L}$. Hence, the obtained results are demonstrated the strength of greywater, which average value is high.

\section{B. AnSBR Pilot Plant Reactor}

The AnSBR process is utilized in this work for removing the anionic surfactants in the range as $84.6 \%$. The AnSBR features are mentioned in Table III.

The COD as well as $\mathrm{BOD}_{5}$ removal has been removed from 356 to 163.2 and $252.8-96 \mathrm{mg} / \mathrm{L}$ that are corresponding to the 54.15 and $62.02 \%$ removal rate. Valuable degradation of organic loads can be achieved due to the anaerobic nature of UASP, and they are converted to biogas. Subsequently, the $\mathrm{BOD}_{5} / \mathrm{COD}$ average ratio is 0.59 (i.e., lower than 0.75 in the raw greywater) in the AnSBR treated effluent. It reduces due to the fact that the rate of removal of organic loads as $\mathrm{BOD}_{5}$ $(62.02 \%)$ that is higher than chemical load as COD $(54.15 \%)$. However, the ratio of $\mathrm{BOD}_{5} / \mathrm{COD}$ in AnSBR treated effluent is still enough to achieve further organic degradation in the 
biological treatment.

TABLE III: THE ANAEROBIC TREATMENT EFFECTS ON CHEMICAL AND PHYSICAL PROPERTIES OF GREYWATER BY ANSBR PARAMETERS

\begin{tabular}{|c|c|c|c|c|c|}
\hline \multirow[t]{2}{*}{ Parameters } & \multirow[t]{2}{*}{ Unit } & \multirow[t]{2}{*}{$\mathrm{N}$} & \multirow{2}{*}{$\begin{array}{l}\text { Synthetic } \\
\text { greywater } \\
\text { (average) }\end{array}$} & \multicolumn{2}{|c|}{ AnSBR effluent } \\
\hline & & & & Concentration & $\begin{array}{l}\text { Efficiency } \\
(\% \mathrm{R})\end{array}$ \\
\hline TSS & $\mathrm{mg} / \mathrm{L}$ & 10 & $142.3 \pm 6.09$ & $114.4 \pm 5.5$ & 19.60 \\
\hline $\begin{array}{l}\text { Anionic } \\
\text { Surfactant }\end{array}$ & $\mathrm{mg} / \mathrm{L}$ & 10 & $46.44 \pm 18.19$ & $7.15 \pm 1.06$ & 84.60 \\
\hline COD & $\mathrm{mg} / \mathrm{L}$ & 10 & $356 \pm 29.51$ & $163.2 \pm 23.61$ & 54.15 \\
\hline $\mathrm{BOD}_{5}$ & $\mathrm{mg} / \mathrm{L}$ & 10 & $252.8 \pm 28.02$ & $96 \pm 21.33$ & 62.02 \\
\hline $\mathrm{BOD}_{5} / \mathrm{COD}$ & Ratio & 10 & $0.71 \pm 0.09$ & $0.59 \pm 0.13$ & - \\
\hline $\mathrm{TP}$ & $\mathrm{mg} / \mathrm{L}$ & 10 & $6.73 \pm 0.69$ & $4.71 \pm 0.47$ & 30.00 \\
\hline $\mathrm{TN}$ & $\mathrm{mg} / \mathrm{L}$ & 10 & $39.94 \pm 3.23$ & $32.82 \pm 1.8$ & 17.83 \\
\hline
\end{tabular}

The inadequate reduction of the TSS, TN, and TP are extended at $19.6 \%, 17.83 \%$, and $30 \%$, respectively. These decreases were from 142 to $114.4 \mathrm{mg} / \mathrm{L}$ for TSS, from 39.94 to 32.82 for $\mathrm{TN}$, and from 6.73 to $4.71 \mathrm{mg} / \mathrm{L}$ for $\mathrm{TP}$. Additionally, the AnSBR is utilized for removing the anionic surfactants, $\mathrm{BOD}_{5}$ and $\mathrm{COD}$, it is still weak in removing TSS, $\mathrm{TN}$, and TP. The calculated COD/TN/TP in the present effluent is $34.65 / 6.96 / 1$, which is in correlation with the values reported by Tchobanoglous et al. [30]. This indicates that there can be very few chances to treat biologically further.

So, AnSBR needs to be modified to bring down the contaminant load. Moreover, the AnSBR influent should be treated by modified AnSBR to reduce the nutrient load on the aerobic system. To obtain the lower total nitrogen limits by biodegradation, biodegradable carbon sources are available immediately for use by refuse organisms. So, it was decided to develop the multistage flow for the AnSBR system, aided with internal circulation in the pilot plant to improve the biological treatment and the further treatment as the aerobic system to remove the concerned pollutants.

\section{Greywater Treatment Using ASBR Pilot Plant Reactor}

The variable aeration times effects of 15-120min are mentioned in Table IV. Thus, the obtained outcomes are demonstrated the high aeration time and the pollutant reduction. Thus, it is used for absorbing the organic matter from the used greywater while enhancing the existing bacteria.

The biological treatment cannot be suitable for further treatment, since the $\mathrm{BOD}_{5} / \mathrm{COD}$ ratio is 0.49 at the maintained aeration time of 120 minutes. The performance of the combined anaerobic-aerobic was found to be limited as far as TSS removal was concerned, they do not comply with local regulatory standards for reuse in irrigation mentioned in Table V. As a result, postoperative treatment was required to control the treated of the combined anaerobic-aerobic treatment process. So, there was a need to select one of the physical treatments, which is capable of low cost, low energy, and less polluting, in operation. Meanwhile, the filtration unit is used to remove turbidity, colloids, suspended solids, and remove microbes present in the biologically treated effluent.

\section{Up-Flow Sand Filter (UFSF) Performance}

The UFSF efficacy for aerobic waste treatment is given in Table VI. Concentrations of $\mathrm{COD}, \mathrm{BOD}_{5}, \mathrm{TN}, \mathrm{TP}$, anionic surfactants, and TSS ranged from 30 to 45,7 to 20,2 to $4,0.7$ to 1,0 to 1 , and 6 to $8 \mathrm{mg} / \mathrm{L}$, respectively. The efficiency of the system for removing these parameters is $30.87,38.04$, $60.99,33.07,81.85$, and $81.09 \%$, respectively.

TABLE IV: AERATION EFFECT AT DisSIMILAR TIMES ON THE CHARACTERISTICS OF CHEMICAL AND PHYSICAL BY AnSBR EFFLUENT

\begin{tabular}{|c|c|c|c|c|c|c|c|c|c|c|c|c|c|}
\hline \multirow[t]{2}{*}{ Constraints } & \multirow[t]{2}{*}{ Unit } & \multirow[t]{2}{*}{$\mathrm{N}$} & \multirow{2}{*}{$\begin{array}{l}\text { AnSBR } \\
\text { effluent } \\
\text { (average) }\end{array}$} & \multicolumn{10}{|c|}{ Aeration time (min) } \\
\hline & & & & 15 & & 30 & & 60 & & 90 & & 120 & \\
\hline TSS & $\mathrm{mg} / \mathrm{L}$ & 10 & $94 \pm 3.4$ & $\sim 88$ & 6.38 & $\sim 79$ & 15.96 & $\sim 68$ & 27.66 & $\sim 53$ & 43.62 & $\sim 40$ & 57.45 \\
\hline COD & $\mathrm{mg} / \mathrm{L}$ & 10 & $176 \pm 16.86$ & $\sim 159.8$ & 9.24 & $\sim 148.65$ & 15.52 & $\sim 135.34$ & 24.1 & $\sim 88.54$ & 49.69 & $\sim 44.8$ & 74.5 \\
\hline $\mathrm{BOD}_{5}$ & $\mathrm{mg} / \mathrm{L}$ & 10 & $99.2 \pm 23.61$ & $\sim 83$ & 16.33 & $\sim 76$ & 23.39 & $\sim 70$ & 29.44 & $\sim 48$ & 51.61 & $\sim 22$ & 77.82 \\
\hline $\mathrm{BOD}_{5} / \mathrm{COD}$ & Ratio & 10 & - & 51.94 & - & 51.13 & - & 51.72 & - & 54.21 & - & 0.49 & - \\
\hline $\mathrm{TP}$ & $\mathrm{mg} / \mathrm{L}$ & 10 & $3.11 \pm 0.33$ & - & - & - & - & - & - & - & - & $\sim 1.32$ & 57.55 \\
\hline $\mathrm{TN}$ & $\mathrm{mg} / \mathrm{L}$ & 10 & $19.82 \pm 2.03$ & $\sim 16.8$ & 15.24 & $\sim 14.2$ & 28.35 & $\sim 11.6$ & 41.47 & $\sim 9.1$ & 54.09 & $\sim 7.48$ & 62.26 \\
\hline
\end{tabular}

*Every AnSBR value effluent parameter is defined based on mean value \pm SD

\section{E. Organic Matter and Nutrient Removal of the Integrated Greywater Treatment Plant}

At anaerobic, aerobic, and sand filter conditions, the influent COD concentration was maintained at $347.87 \mathrm{mg} / \mathrm{L}$ at the pilot plant. Operating conditions were maintained at $\mathrm{COD} / \mathrm{N} / \mathrm{P}$ ratio of 53.27/6.23/1, HRT=24hrs. $\mathrm{X}=1-2 \mathrm{~g} / \mathrm{L}$ and $\mathrm{DO}=3.5-4.5 \mathrm{mg} / \mathrm{L}$; the outgoing COD concentration decreases to $175.2 \mathrm{mg} / \mathrm{L}$ giving the AnSBR a removal capacity of $49.64 \%$. The maximum COD removal capacity is
$84.27 \%$ that is attained for ASBR. From Fig. 3(a), proves that the removal capacity enhances through increasing influential COD concentration. The pilot-plant showed a total removal of $89.12 \%$ of COD after the sand filtration phase, at organic loading rates measuring $3.5 \mathrm{~kg} \mathrm{COD} / \mathrm{m}^{3} / \mathrm{day}$.

In the present study, the mean ratio of $\mathrm{BOD} / \mathrm{COD}$ in the influent greywater was 0.74 to 0.76 . Therefore, there was the right amount of biodegradable organic matter presented in greywater, which can be consumed or biodegraded by bacteria during the anaerobic and aerobic stages. The effluent 
BOD concentration decreased to $92.98 \mathrm{mg} / \mathrm{L}$ yielding a removal efficiency of $64.24 \%$ in AnSBR. The BOD removal efficiency of aerobic effluent was obtained around $86.04 \%$ in ASBR. From the final waste generated from the sand filter, the BOD concentration was reduced to $13.26 \mathrm{mg} / \mathrm{L}$, which gave the ability to remove $94.9 \%$ of the $2.6 \mathrm{~kg} \mathrm{BOD} / \mathrm{m}^{3} /$ day (Fig. 3b) measured organic loading rates.

TABLE V: TREATED GREYWATER REUSE IN IRRIGATION GUIDELINES AND REGULATIONS [1], [20]

\begin{tabular}{|c|c|c|c|c|c|c|c|c|c|c|c|c|}
\hline \multirow[t]{2}{*}{ Constraint } & \multicolumn{2}{|l|}{ India } & \multicolumn{2}{|l|}{ US EPA } & \multicolumn{2}{|l|}{ Australia } & \multicolumn{2}{|l|}{ Italy } & \multicolumn{2}{|l|}{ Jordan } & \multicolumn{2}{|l|}{ China } \\
\hline & Irrigation & Reuse & Irrigation & Reuse & Irrigation & Reuse & Irrigation & Reuse & Irrigation & Reuse & Irrigation & Reuse \\
\hline $\begin{array}{l}\text { Total Suspended solids mg/l, } \\
\text { Max. }\end{array}$ & 200 & 200 & 30 & - & - & - & - & 10 & 150 & $50-150$ & - & $10.0-50.0$ \\
\hline $\mathrm{pH}$ & $5.5-9$ & $6.0-9.0$ & $6.0-9.0$ & $6.0-9.0$ & $4.5-9$ & - & - & $6.0-9.5$ & $6.0-9.0$ & $6.0-9.0$ & - & $6.0-9.0$ \\
\hline BOD & 30 & 30 & 30 & 10 & 20 & 20 & - & 20 & 300 & $30-300$ & - & $10.0-20.0$ \\
\hline COD & - & - & - & - & - & - & - & 100 & 500 & $100-500$ & - & 15 \\
\hline Turbidity & 20 & 2 & 5 & 5 & 30 & 10 & - & - & 25 & $2.0-10.0$ & - & 10 \\
\hline $\mathrm{TN}$ & 30 & 10 & - & - & - & - & - & 15 & 70 & $50-70$ & - & $15-20$ \\
\hline $\mathrm{TP}$ & $6.0-8.0$ & 1 & - & - & - & - & - & 2 & - & 30 & - & $1.0-5.0$ \\
\hline
\end{tabular}

TABLE VI: THE UFSF EFFECT OF GREYWATER ON CHEMICAL AND PHYSICAL PROPERTIES

\begin{tabular}{llllll}
\hline \hline Parameters & Unit & $\mathrm{N}$ & $\begin{array}{l}\text { Aerobic } \\
\text { effluent }\end{array}$ & Concentration & $\begin{array}{l}\text { Efficiency } \\
(\% \mathrm{R})\end{array}$ \\
\hline TSS & $\mathrm{mg} / \mathrm{L}$ & 10 & $38.34 \pm 3.25$ & $7.25 \pm 0.87$ & 81.09 \\
Anionic & $\mathrm{mg} / \mathrm{L}$ & 10 & $2.26 \pm 1.9$ & $0.41 \pm 0.5$ & 81.85 \\
$\begin{array}{l}\text { Surfactant } \\
\text { COD }\end{array}$ & $\mathrm{mg} / \mathrm{L}$ & 10 & $54.75 \pm 15.22$ & $37.85 \pm 7.28$ & 30.87 \\
BOD & $\mathrm{mg} / \mathrm{L}$ & 10 & $21.40 \pm 12.85$ & $13.26 \pm 6.12$ & 38.04 \\
TP & $\mathrm{mg} / \mathrm{L}$ & 10 & $1.27 \pm 0.64$ & $0.85 \pm 0.12$ & 33.07 \\
$\mathrm{TN}$ & $\mathrm{mg} / \mathrm{L}$ & 10 & $7.82 \pm 3.2$ & $3.05 \pm 0.87$ & 60.99 \\
\hline \hline
\end{tabular}

*Each value of the parameter is described as the mean value \pm SD

The effluent of TN concentration decreased to $18.19 \mathrm{mg} / \mathrm{L}$ yielding a removal efficiency of $55.35 \%$ in AnSBR. The TN removal efficiency of aerobic effluent was obtained around $80.8 \%$ in aerobic SBR. From the final effluent generated from the sand filter, the concentration of TN was reduced to $6.05 \mathrm{mg} / \mathrm{L}$ yielding a removal efficiency of $85.15 \%$ (Fig. 4).
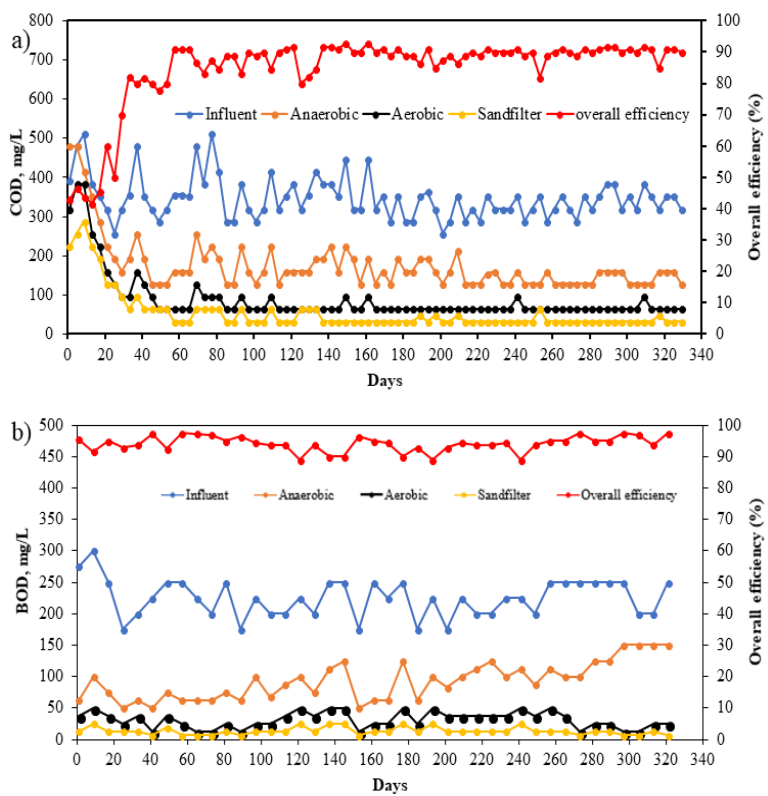

Fig. 3. Overall removal efficiencies of organic matter (a) COD (b) BOD in anaerobic, aerobic, and sand filter stages.
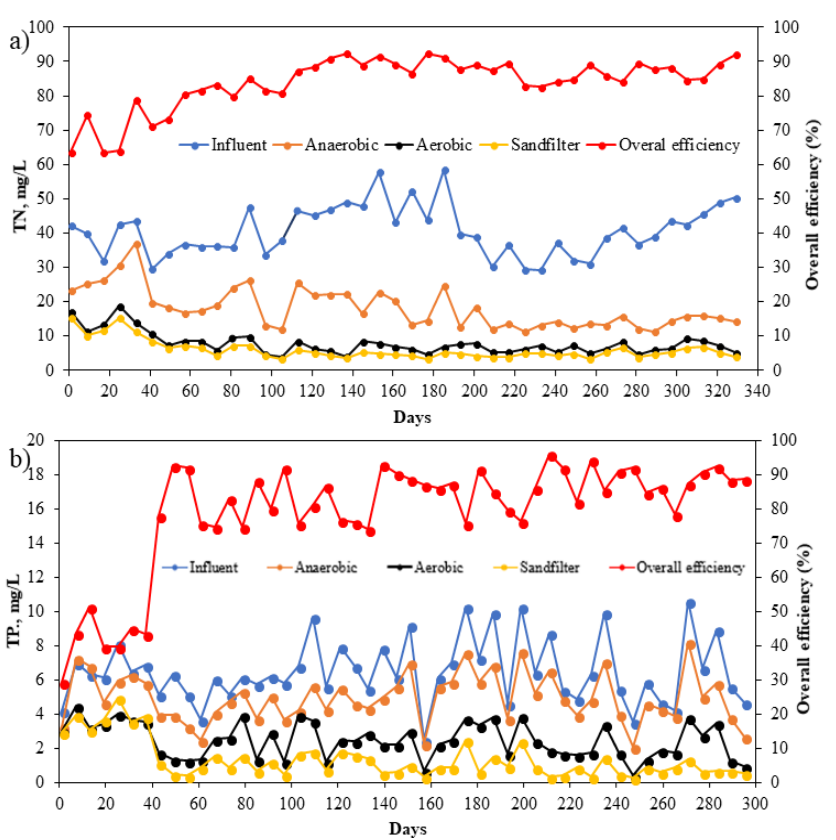

Fig. 4. Overall removal efficiencies of nutrients (a) TN (b) TP in anaerobic, aerobic, and sand filter stages.

The overall performance of the integrated system is shown in Table VII. The pilot plant has been controlled and monitored with the observation of $\mathrm{pH}$ conditions since the micro-organisms in biological treatment depend on the optimal $\mathrm{pH}$ values. The dissolved solids concentrations have not exceeded more than $1000 \mathrm{mg} / \mathrm{L}$, which satisfied the effluent standards' limits. The anionic surfactant, TP, $\mathrm{NH}_{4}^{+}-\mathrm{N}, \mathrm{NO}_{3}^{-}-\mathrm{N}$, TSS, and sulphates concentrations decreased to $5.66,2.98,16.32,2.41,92.4$, and $10.92 \mathrm{mg} / \mathrm{L}$, yielding the removal efficiency of $87.82,54.36,32.73,72.61$, 34.88 , and $72.11 \%$, respectively, in AnSBR. Of these contaminants, TSS and $\mathrm{NH}_{4}^{+}-\mathrm{N}$ have been shown inadequate removal during the anaerobic phase due to the decomposition of nitrogenous organic matter (Yang et al. 2015). The removal efficiencies of anionic surfactant, TP, $\mathrm{NH}_{4}^{+}-\mathrm{N}, \mathrm{NO}_{3}^{-}-\mathrm{N}, \mathrm{TSS}$, and sulphates were obtained to be $95.13,80.55,90.23,72.98$, and $75.45 \%$, respectively, in ASBR. 
TABLE VII: EFFECT OF GREYWATER OVERALL TREATMENT OF CHEMICAL AND PHYSICAL CHARACTERISTICS

\begin{tabular}{|c|c|c|c|c|c|c|c|c|c|c|}
\hline \multirow[t]{2}{*}{ Parameter } & \multirow[t]{2}{*}{ Unit } & \multirow[t]{2}{*}{$\mathrm{N}$} & \multirow[t]{2}{*}{ Feeding Tank } & \multicolumn{2}{|c|}{$\begin{array}{c}\text { Anaerobic } \\
\text { effluent }\end{array}$} & \multicolumn{2}{|c|}{$\begin{array}{l}\text { Aerobic } \\
\text { effluent }\end{array}$} & \multicolumn{2}{|c|}{$\begin{array}{c}\text { Sand filter } \\
\text { effluent }\end{array}$} & \multirow{2}{*}{$\begin{array}{c}\text { Overall } \\
\text { efficiency } \\
\% \mathrm{R}\end{array}$} \\
\hline & & & & Concentration & $\% \mathrm{R}$ & Concentration & $\% \mathrm{R}$ & Concentration & $\% \mathrm{R}$ & \\
\hline $\mathrm{pH}$ & & 45 & $7.1 \pm 0.39$ & $6.79 \pm 0.41$ & - & $7.00 \pm 0.32$ & - & $7.15 \pm 0.33$ & - & - \\
\hline $\mathrm{EC}$ & $\mu \mathrm{S} / \mathrm{cm}$ & 45 & $262.35 \pm 48$ & $584.58 \pm 157.3$ & - & $533.97 \pm 94$ & - & $551.15 \pm 88.7$ & - & - \\
\hline Dissolved Oxygen & $\mathrm{mg} / \mathrm{L}$ & 45 & $4.72 \pm 0.6$ & $1.53 \pm 0.49$ & - & $3.9 \pm 0.53$ & - & $4.9 \pm 0.63$ & - & - \\
\hline$N H_{4}^{+}-N$ & $\mathrm{mg} / \mathrm{L}$ & 45 & $24.26 \pm 2.3$ & $16.32 \pm 1.9$ & 32.73 & $7.26 \pm 1.6$ & 55.51 & $2.78 \pm 0.29$ & 61.71 & 88.54 \\
\hline Nitrate Nitrogen & $\mathrm{mg} / \mathrm{L}$ & 45 & $8.8 \pm 0.95$ & $2.41 \pm 0.63$ & 72.61 & $0.86 \pm 0.12$ & 64.31 & $0.57 \pm 0.22$ & 33.72 & 93.52 \\
\hline TN & $\mathrm{mg} / \mathrm{L}$ & 45 & $40.73 \pm 7.3$ & $18.19 \pm 5.9$ & 55.34 & $7.82 \pm 3.2$ & 57 & $6.05 \pm 2.87$ & 22.63 & 85.15 \\
\hline COD & $\mathrm{mg} / \mathrm{L}$ & 45 & $347.87 \pm 49$ & $175.21 \pm 36.7$ & 49.63 & $54.75 \pm 15.22$ & 68.75 & $37.85 \pm 7.28$ & 30.87 & 89.12 \\
\hline BOD & $\mathrm{mg} / \mathrm{L}$ & 45 & $260 \pm 30.1$ & $92.98 \pm 30.02$ & 64.23 & $21.40 \pm 12.85$ & 76.98 & $13.26 \pm 6.12$ & 38.04 & 94.9 \\
\hline Phosphates & $\mathrm{mg} / \mathrm{L}$ & 45 & $6.53 \pm 1.89$ & $2.98 \pm 1.45$ & 54.36 & $1.27 \pm 0.64$ & 57.38 & $0.85 \pm 0.12$ & 33.07 & 86.98 \\
\hline TSS & $\mathrm{mg} / \mathrm{L}$ & 45 & $141.9 \pm 5.89$ & $92.4 \pm 4.5$ & 34.88 & $38.34 \pm 3.25$ & 58.5 & $16.25 \pm 2.12$ & 57.62 & 88.5 \\
\hline Surfactants & $\mathrm{mg} / \mathrm{L}$ & 45 & $46.44 \pm 18.19$ & $5.66 \pm 3.06$ & 87.81 & $2.26 \pm 1.9$ & 60 & $0.41 \pm 0.15$ & 81.8 & 99.11 \\
\hline Sulphates & $\mathrm{mg} / \mathrm{L}$ & 45 & $39.15 \pm 3.22$ & $10.92 \pm 1.36$ & 72.11 & $9.61 \pm 1.12$ & 12 & $7.64 \pm 0.88$ & 20.5 & 80.48 \\
\hline
\end{tabular}

*The parameter value was defined based on mean value \pm SD

The $\mathrm{NH}_{4}^{+}-\mathrm{N}$ removal efficiency was improved $(\sim 55.5)$ at the aerobic stage due to the adequate nitrification process and also the increase in TSS removal $(\sim 58.5 \%)$ since the SBR systems are advantageous due to the possibility to carry out the replacement of substrates in a single unit (aeration reactor and secondary clarifier).In the final effluent generated from the sand filter, the concentrations of anionic surfactant, TP, $\mathrm{NH}_{4}^{+}-\mathrm{N}, \mathrm{NO}_{3}^{-}-\mathrm{N}$, TSS, and sulphates were reduced to $0.41,0.85,2.78,0.57,7.25$, and $7.64 \mathrm{mg} / \mathrm{L}$, yielding removal efficiencies of $99,86.98,88.54,93.52,94.89$ and $80.49 \%$, respectively.

\section{F. Hydrodynamic Studies in Integrated System}

Like dyes, salts can be used to measure the stay of water in a system. The known quantity and salt concentration are added to a system and measured from an outlet by electrical conductivity changes. Chloride represents an effective tracer because it is relatively inactive and has not been used extensively by biota. Nitrate can be a bad tracer because it can be ingested by biota before leaving the system [31].

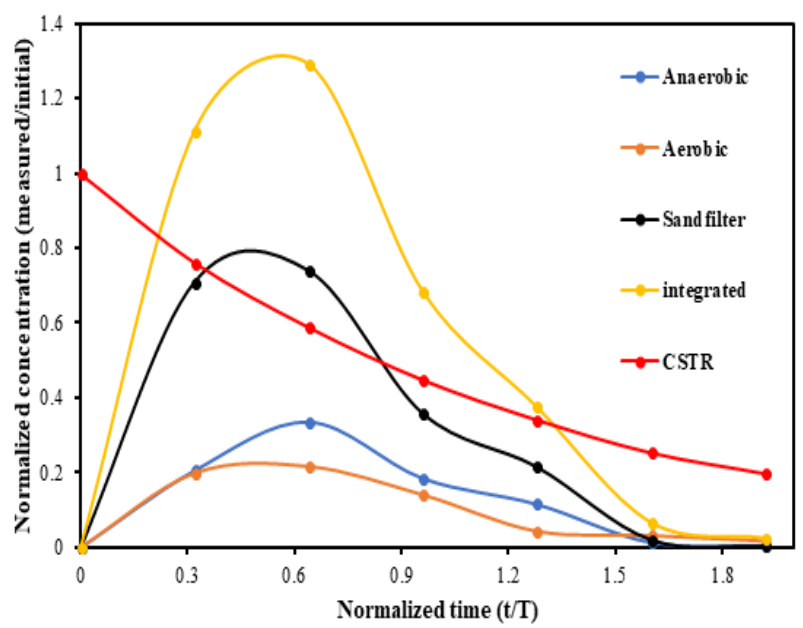

Fig. 5. Normalized time vs normalized concentration.

To analyze the hydrodynamics of the integrated system, residential time distribution (RTD) curves have been arranged by the $\mathrm{NaCl}$ solution as a tracer. The electric conductivity of tap water $=70.6 \mu \mathrm{S} / \mathrm{cm}$, The Electric conductivity of $\mathrm{NaCl}$ injected in tap water $=1164.8 \mu \mathrm{S} / \mathrm{cm}$
(733 mg/L concentration). Electric conductivity of $\mathrm{NaCl}$ excluding tap water $=1094.2 \mu \mathrm{S} / \mathrm{cm}$. Therefore, $\mathrm{NaCl}$ concentration $(\mathrm{mg} / \mathrm{L})=$ Conductivity value $(\mu \mathrm{s} / \mathrm{cm}) / 0.67$. The results of the calculations show that the effluent to total salt ratio is $70.69 \%$, which is equal to $\mathrm{F}(\mathrm{t})$. A good deal of the salt remains in the reactor, which suggests that a total of $29.3 \%$ of the salt had already been remained in the reactor.

The utilized test parameters of this process are detailed as below: The influent $\mathrm{Q}=100 \mathrm{~L} /$ day $=0.0042 \mathrm{~m}^{3} / \mathrm{h}, \mathrm{T}=24$ $\mathrm{h}=1440$ min. The normalized RTD curves generated by the tracer probe at 24-h HRT are shown in Fig. 5. Moreover, the calculated results of the hydrodynamic properties are detailed in Table VIII. The $\overline{\mathrm{t}}$ of the system is $16.73 \mathrm{~h}$ that indicates the actual exposure time of the system which is less than HRT.

TABLE VIII: CALCULATION RESULTS FOR TRACER ANALYSIS

\begin{tabular}{|c|c|c|c|c|}
\hline $\begin{array}{l}\text { S. } \\
\text { No }\end{array}$ & Parameters & Anaerobic & Aerobic & Sand filter \\
\hline 1 & $\begin{array}{l}\text { Mean } \\
\text { retention time, } \\
\overline{\mathrm{t}}, \text { min }\end{array}$ & 1003.43 & 996.36 & 1012.805334 \\
\hline 2 & Variance, $\sigma^{2}$ & 122.78 & 126.78 & 119.5679126 \\
\hline 3 & $\sigma_{\Theta}^{2}$ & 0.00012194 & 0.00012771 & 0.000116564 \\
\hline 4 & $\begin{array}{l}\text { Dispersion } \\
\text { number, D/UL }\end{array}$ & $6.0972 \mathrm{E}-05$ & $6.38551 \mathrm{E}-05$ & $5.82818 \mathrm{E}-05$ \\
\hline 5 & $\mathrm{~F}(\mathrm{t})$ & 0.83 & 0.8 & 0.83 \\
\hline 6 & $\begin{array}{l}\text { Dimensionless } \\
\text { time, } \theta\end{array}$ & 1.44 & 1.45 & 1.42 \\
\hline
\end{tabular}

The dead space of the model acts as the necessary part that can affect the $\bar{t}$ and integrated system efficiency. Moreover, $30.3 \%$ dead space was identified in the system that demonstrating the substrate satisfactory distribution within the integrated system. Furthermore, a plug-flow regime suggested that the lower value of D/UL obtained for anaerobic tank, aerobic tank, and sand filter as 6.0972E-05, $6.38551 \mathrm{E}-05$, and $5.82818 \mathrm{E}-05$, respectively, may be considered to have this structure [28].

Moreover, $F(t)$ values of effluent salt ratio from the anaerobic tank, aerobic tank, and sand filter to the inlet are $0.83,0.8$, and 0.83 . The results show that the leftover $\mathrm{NaCl}$ of total salt in the anaerobic tank, aerobic tank, and sand filter is $17 \%, 20 \%$, and $17 \%$, respectively. Comparison of organic matter and nutrient removal efficiencies of integrated 
anaerobic, aerobic, and sand filter system and other detailed in Table IX. combined biological treatment systems for greywater are

TABLE IX: COMPARISON OF ORGANIC MATTER AND NUTRIENT REMOVAL EFFICIENCIES OF INTEGRATED ANAEROBIC, AEROBIC, AND SAND FILTER SYSTEM AND OTHER COMBINED BIOLOGICAL TREATMENT SYSTEMS FOR GReywater

\begin{tabular}{|c|c|c|c|c|c|c|c|c|c|}
\hline \multirow[t]{2}{*}{ Reference } & \multirow[t]{2}{*}{ Technology } & \multicolumn{2}{|c|}{ Organic loading rate } & \multirow[t]{2}{*}{ HRT (h) } & \multicolumn{5}{|c|}{ Removal efficiency (\%) } \\
\hline & & $\begin{array}{c}\mathrm{Kg} \\
\mathrm{COD} / \mathrm{m}^{3} * \text { day }\end{array}$ & $\begin{array}{c}\mathrm{Kg} \\
\mathrm{BOD} / \mathrm{m}^{3} * \text { day }\end{array}$ & & $\mathrm{COD} \%$ & BOD $\%$ & $\mathrm{NH}_{4}^{+}-\mathrm{N} \%$ & $\mathrm{TN} \%$ & $\mathrm{TP} \%$ \\
\hline Present Study & $\begin{array}{l}\text { Integrated anaerobic, aerobic, and sand } \\
\text { filter }\end{array}$ & 3.5 & 2.6 & 24 & 89.12 & 94.9 & 88.54 & 85.15 & 86.98 \\
\hline $\begin{array}{c}\text { Priyanka et } \\
\text { al. }[32]\end{array}$ & Sequencing batch reactor & - & - & 24 & 96.2 & 97.38 & 81.68 & - & 72 \\
\hline $\begin{array}{l}\text { Abdel-Shafy } \\
\text { et al. }[19]\end{array}$ & $\begin{array}{c}\text { Anaerobic/aerobic integration via } \\
\text { UASB/enhanced aeration }\end{array}$ & 1.93 & 1.1 & 24 & 98.4 & 98.3 & 95.3 & 94 & 90.5 \\
\hline $\begin{array}{c}\text { Tombola et } \\
\text { al. }[8]\end{array}$ & Sequencing batch biofilm reactor & - & - & 24 & 86.5 & - & 98.4 & 71.4 & - \\
\hline $\begin{array}{l}\text { Eslami et al. } \\
\qquad[26]\end{array}$ & $\begin{array}{l}\text { Integrated fixed-film activated sludge } \\
\text { (IFAS) }\end{array}$ & $0.11-1.3$ & - & 8.1 & 93 & 85 & - & 90 & 87 \\
\hline $\begin{array}{l}\text { Saidi et al. } \\
\quad[33]\end{array}$ & Multistage moving bed biofilm reactor & 3.4 & 2.8 & $28.8-38.4$ & 94.5 & 99.4 & 99.7 & 63 & 14 \\
\hline $\begin{array}{l}\text { Abdel-Shafy } \\
\text { et al. }[18]\end{array}$ & $\begin{array}{c}\text { Anaerobic/aerobic integration via UASB } \\
\text { and MBR }\end{array}$ & 1.93 & 1.1 & $7.5-10.5$ & 97.8 & 97.4 & 94.5 & - & 89.8 \\
\hline $\begin{array}{l}\text { Merz et } \\
\text { al. }[34]\end{array}$ & Membrane bioreactor technology & $0.09-0.21$ & - & $9-18$ & 85 & 94 & 72 & - & 19 \\
\hline $\begin{array}{c}\text { Hernández } \\
\text { Leal } \text { et al. } \\
\text { [35] }\end{array}$ & Aerobic treatment & $0.15-8$ & - & $12-24$ & 90 & - & - & - & - \\
\hline $\begin{array}{l}\text { Friedler et al. } \\
\qquad[36]\end{array}$ & $\begin{array}{c}\text { Screening, Rotating biological contractors, } \\
\text { Chlorination }\end{array}$ & - & - & - & 75 & 96 & 96 & - & 58 \\
\hline
\end{tabular}

\section{CONCLUSION}

Greywater can be reused for irrigation if satisfactory and appropriate treatment is obtained using the integrated treatment methods provided. The integrated aerobic-aerobic sequence batch reactor for greywater treatment is a practical, low cost and feasible process. The use of an integrated system provides the following greywater purification efficiency based on the following findings.

- The removal capacity of the pilot plant for COD, BOD, anionic surfactants, TN, TSS and TP is $89 \%, 95 \%, 99 \%$, $85 \%, 88.5$ and $87 \%$ respectively.

- The integrated system provided significant removal performance of anionic surfactants, COD, BOD, TN, and $\mathrm{TP}$, while the system maintained at $\mathrm{COD} / \mathrm{N} / \mathrm{P}$ is 53.27/6.23/1, X (MLVSS) in the range 1-1.5 g/L, HRT-24 hrs., DO in the scope of $2.5-4.5 \mathrm{mg} / \mathrm{L}$ and OLR of $3.5 \mathrm{~kg}$ $\mathrm{COD} / \mathrm{m}^{3}$. d $\left(2.6 \mathrm{~kg} \mathrm{BOD} / \mathrm{m}^{3} . \mathrm{d}\right)$.

- The mean residence time (t) was $16.73 \mathrm{~h}$, which is less than the theoretical HRT (T). Furthermore, the dead space size of the whole system is about $30.3 \%$, which represents a moderately low value the integrated systems. In future to optimize the greywater treatment parameter and time consumption, a hybrid optimization will be implemented in this greywater treatment model. Hence, the greywater treatment design could be enhanced and will get optimized result.

\section{CONFLICT OF INTEREST}

The authors declare no conflict of interest.

\section{AUTHOR CONTRIBUTIONS}

Sarath Chandra Pragada: Conceptualization; Formal analysis; Methodology; Conducted the research; Analyzed the data; validation; Visualization - original draft. Arun Kumar Thalla: Conceptualization; Investigation; Funding acquisition; Supervision; Writing - review \& editing. All authors had approved the final version.

\section{ACKNOWLEDGMENT}

The Authors thank Ms. Anju Anna John, Junior Research Fellow, for her help in carrying out the experimental work.

\section{REFERENCES}

[1] F. Boano, A. Caruso, E. Costamagna, L. Ridolfi, S. Fiore, F. Demichelis, A. Galvão, J. Pisoeiro, A. Rizzo, and F.Masi, "A review of nature-based solutions for greywater treatment: Applications, hydraulic design, and environmental benefits," Sci. Total Environ., vol. 711, p. 134731, 2020.

[2] F. E. Eregno and A.Heistad, "On-site treated wastewater disposal systems - The role of stratified filter medias for reducing the risk of pollution," Environ. Int., vol. 124, pp. 302-311, 2019

[3] T. Z. Shoa, M. Barjenbruch, and A.Wriege-Bechtold, "Source separation technologies, opportunities for sustainable wastewater management," Eur. Water, vol. 58, pp. 111-117, 2017.

[4] M. Gorgich, T. M. Mata, A. Martins, N. S. Caetano, and N. Formigo, "Application of domestic greywater for irrigating agricultural products: A brief study," Energy Reports, vol. 6, pp. 811-817, 2020.

[5] Khuntia, H. Kumar et al., "Greywater treatment in aerobic bio-reactor with macropore mesh filters," Journal of Water Process Engineering, vol. 28, 2019, pp. 269-276.

[6] F. W. Kariuki, K. Kotut, and V. G.Ngángá, "The potential of a low cost technology for the greywater treatment," pp. 32-39, 2011.

[7] D. R. Samayamanthula, C. Sabarathinam, and H.Bhandary, "Treatment and effective utilization of greywater," Appl. Water Sci., vol. 9, no. 4, pp. 1-12, 2019. 
[8] R. Tombola, G. Buttiglieri, M. Auset, and R. Gonzalez-Olmos, "Recycled corrugated wire hose cover as biological carriers for greywater treatment in a sequential batch biofilm reactor," J. Environ. Manage., vol. 240, pp. 475-484, February 2019.

[9] L. A. Ghunmi, G. Zeeman, M. Fayyad, and J. B. Lier, "Grey water treatment systems: A review," Crit. Rev. Environ. Sci. Technol., vol. 41 no. 7, pp. 657-698, 2011.

[10] Khuntia, H. Kumar, S. Chandrashekar, and H. N. Chanakya "Treatment of household greywater laden with household chemical products in a multi-chambered anaerobic biofilm reactor," Sustainable Cities and Society, vol. 51, 2019, p. 101783.

[11] R. Khalaphallah, "Greywater treatment for reuse by slow sand filtration: Study of pathogenic microorganisms and phage survival," 2012.

[12] F. Li, K. Wichmann, and R.Otterpohl, "Review of the technological approaches for grey water treatment and reuses," Sci. Total Environ., vol. 407, no. 11, pp. 3439-3449, 2009.

[13] C. Huang, Y. Shi, M. Gamal El-Din, and Y. Liu, "Performance of flocs and biofilms in integrated fixed-film activated sludge (IFAS) systems for the treatment of oil sands process-affected water (OSPW)," Chem. Eng. J., vol. 314, pp. 368-377, March 2017.

[14] Khuntia, H. Kumar, N. Janardhana, and H. N. Chanakya, "Household discharge of chemical products and its classification based on anaerobic biodegradability," Environmental Monitoring and Assessment, vol. 193, no. 1, 2021, pp. 1-15.

[15] M. Oteng-Peprah, M. A. Acheampong, and N. K.deVries, "Greywater Characteristics, Treatment Systems, Reuse Strategies and User Perception - A review," Water. Air. Soil Pollut., vol. 229, no. 8, 2018.

[16] Z. Erlangung and D. E.Weingärtner, Greywater Characteristics, Biodegradability and Reuse of some Greywaters, 2013.

[17] J. Laaffat, F. Aziz, N. Ouazzani, and L.Mandi, "Biotechnological approach of greywater treatment and reuse for landscape irrigation in small communities," Saudi J. Biol. Sci., vol. 26, no. 1, pp. 83-90, 2019.

[18] H. I. Abdel-Shafy, A. M. Al-Sulaiman, and M. S. M. Mansour, "Anaerobic/aerobic treatment of greywater via UASB and MBR for unrestricted reuse," Water Sci. Technol., vol. 71, no. 4, pp. 630-637, 2015.

[19] H. I. Abdel-Shafy, M. S. M. Mansour, and A. M. Al-Sulaiman, "Anaerobic/aerobic integration via UASB/enhanced aeration for greywater treatment and unrestricted reuse," Water Pract. Technol., vol. 14 , no. 4 , pp. 1-14, 2019.

[20] A. Albalawneh and T. K. Chang, "Review of the greywater and proposed greywater recycling scheme for agricultural irrigation reuses," Artic. Int. J. Res., vol. 3, no. 12, pp. 16-35, 2015.

[21] European Environment Agency, "Climate impacts on water resources," Eur. Environ., Agency, 2007.

[22] L. A. Ghunmi, G. Zeeman, M. Fayyad, and J. B. van Lier, "Grey water treatment in a series anaerobic - Aerobic system for irrigation," Bioresour. Technol., vol. 101, no. 1, pp. 41-50, 2010.

[23] E. Gašpariková, Š. Kapusta, I. Bodík, J. Derco, and K. Kratochvíl, "Evaluation of anaerobic-aerobic wastewater treatment plant operations," Polish J. Environ. Stud., vol. 14, no. 1, pp. 29-34, 2005.

[24] K. Ansari and A. N. Shrikhande, "Feasibility on grey water treatment by electrocoagulation process: A review," Int. J. Emerg. Technol., vol. 10, no. 1, pp. 85-92, 2019.

[25] O. Alagha, A. Allazem, A. A.Bukhari, I. Anil, and N. D. Mu'azu, "Suitability of SBR for wastewater treatment and reuse: Pilot-scale reactor operated in different anoxic conditions," Int. J. Environ. Res. Public Health, vol. 17, no. 5, 2020.

[26] H. Eslami, M. H. Ehrampoush, M. T. Ghaneian, M. Mokhtari, and A.Ebrahimi, "Effect of organic loading rates on biodegradation of linear alkyl benzene sulfonate, oil and grease in greywater by
Integrated Fixed-film Activated Sludge (IFAS)," J. Environ. Manage., vol. 193, pp. 312-317, 2017.

[27] E. W. Rice, R. B. Baird, and A.D. Eaton, "Standard methods for the examination of water and wastewater 23rd edition," Am. Public Heal. Assoc. Am. Water Work. Assoc, 2017

[28] M. K. Sharma and A. A.Kazmi, "Performance evaluation of a single household anaerobic packaged system for onsite domestic wastewater treatment," Desalin. Water Treat., vol. 57, no. 20, pp. 9216-9225 2016.

[29] A. K. Thalla, D. Chella, and M. Torrijos, "Experimental Evaluation of Activated Sludge-Biofilm Reactor: Influence of Composite Media," $J$. Hazardous, Toxic, Radioact. Waste, vol. 16, no. 2, pp. 134-141, 2012.

[30] G. Tchobanoglous, F. L. Burton, and H. D. Stensel, "Waste water engineering treatment and reuse, 4th ed. Ta," Metcalf Eddy, 2003.

[31] F. Licciardello, A. Sacco, S. Barbagallo, D. Ventura, and G. L. Cirelli, "Evaluation of different methods to assess the hydraulic behavior in horizontal treatment wetlands," Water (Switzerland), vol. 12, no. 8, pp. $1-18,2020$.

[32] K. Priyanka, M. Behera, and R. Neelancherry, "Graywater treatment in sequencing batch reactor using simultaneous nitrification, denitrification, and phosphorus removal, with kinetic studies of phosphate adsorption onto corncob," J. Hazardous, Toxic, Radioact Waste, vol. 24, no. 3, pp. 1-8, 2020.

[33] A. Saidi, K. Masmoudi, E. Nolde, B. Amrani, and F. Amraoui, "Organic matter degradation in a greywater recycling system using a multistage moving bed biofilm reactor (MBBR)," Water Sci. Technol., vol. 76, no. 12, pp. 3328-3339, 2017.

[34] C. Merz, R. Scheumann, B. El, and M. Kraume, "Membrane bioreactor technology for the treatment of greywater from a sports and leisure club," vol. 215, pp. 37-43, 2007.

[35] L. H. Leal, G. Zeeman, H. Temmink, and C. Buisman, "Characterisation and biological treatment of greywater," Water Sci. Technol., vol. 56, no. 5, pp. 193-200, 2007

[36] E. Friedler, R. Kovalio, and N. I. Galil, "On-site greywater treatment and reuse in multi-storey buildings," Water Sci. Technol., vol. 51, no. 10 , pp. $187-194,2005$

Copyright (C) 2021 by the authors. This is an open access article distributed under the Creative Commons Attribution License which permits unrestricted use, distribution, and reproduction in any medium, provided the original work is properly cited (CC BY 4.0).

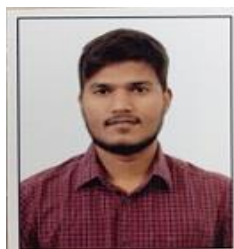

Sarath Chandra Pragada is a research scholar in civil engineering at the National Institute of Technology, India. He worked as a junior research fellow in Indian Institute of Technology, Hyderabad His research interests in the area of biological treatment of liquid wastes, mathematical modelling of bioreactors, photocatalysis, catalyst preparation.

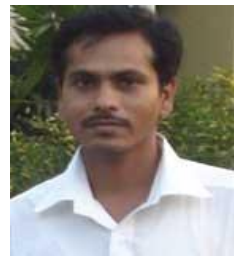

Arun Kumar Thalla is an associate professor in the Department of Civil Engineering at the National Institute of Technology. He has ten years of professional experience. His areas of interest include bioenergy from waste, mathematical modelling of bioreactors, physio-chemical treatments for liquic waste management, LCA for an integrated bio refiners, regional flood analysis and soil moisture 